\title{
Climate Change Mitigation Technologies and Policies in Building Sector
}

\author{
Li Muqi \\ Research Center, Urbanspace Planning and Architectural Design CO., LTD, Beijing, China
}

\section{Email address:}

limuuuqi@163.com

\section{To cite this article:}

Li Muqi. Climate Change Mitigation Technologies and Policies in Building Sector. International Journal of Architecture, Arts and Applications. Vol. 4, No. 3, 2018, pp. 38-46. doi: 10.11648/j.ijaaa.20180403.12

Received: August 19, 2018; Accepted: October 29, 2018; Published: November 10, 2018

\begin{abstract}
Observational evidence from different aspects, such as temperature, sea level, etc., has brought climate change to the attention. The impacts caused by it will vary regionally but will increase over time as global temperatures increase. Many adaptation and mitigation options can help address climate change. While buildings hold important key to effectively addressing climate change by applying mitigation technologies and policies because buildings accounts for large part of global final energy use and greenhouse gas emissions. This paper focuses on climate change mitigation in building sector so as to find out proper methods to reduce greenhouse gas emissions and enhance resilience to climate change. It summarizes the mitigation technologies in building sector, its opportunities and challenges, and sectoral polices. Then it analyzes the roles of stakeholders in building sector. Finally, the mitigation in Norway, which is with high vulnerabilities, is stated as a case study to present a country's responses to climate change in building sector. It has been proved that applying appropriate mitigation technologies and policies, and integrating different stakeholders together properly with recognizing their roles can effectively make a great effort to global climate change mitigation. Only when climate change is regard as important and mitigation technologies and policies are applied properly especially in building sector, can we achieve the sustainable development.
\end{abstract}

Keywords: Climate Change, Mitigation Technology, Building Sector, Norway

\section{Introduction}

Observations and evidence have proved that the Earth is warming with the average temperature risen by $1.3^{\circ} \mathrm{F}$ to $1.9^{\circ} \mathrm{F}$ since 1895 . [1] And this warming has been driven primarily by human activities.

\subsection{Current Climate Change}

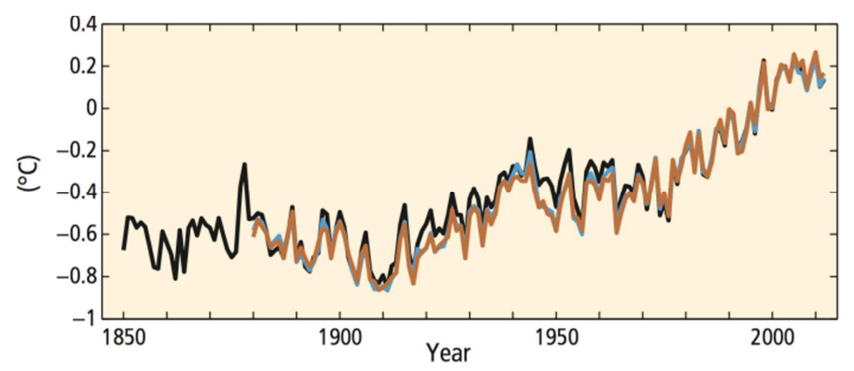

Figure 1. Globally averaged combined land and ocean surface temperature anomaly [2].

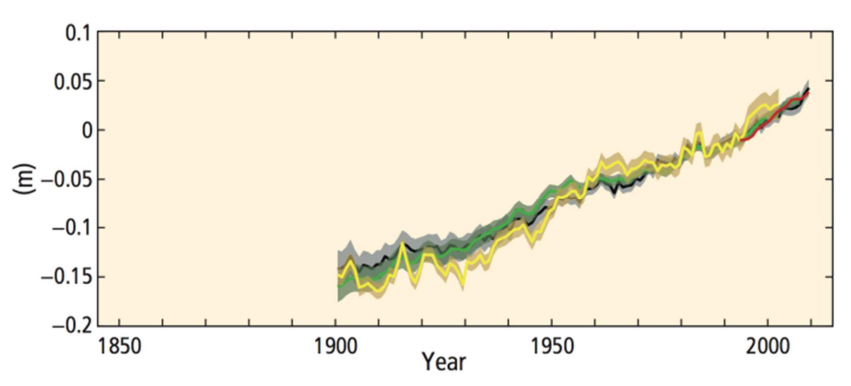

Figure 2. Globally averaged sea level change [2].

Climate change is becoming widely recognized as the key global challenge and urgent problem in this century. IPCC has claimed that warming of the climate system is unequivocal and that results in the amounts of snow and ice have diminished, and sea level has risen. [2]

In addition to the robust warming condition, changes in climate have caused different kinds of impacts on natural and human systems.

In natural systems, the climate where many species live 
influences key stages of their annual life cycle and life habits, such as migration, blooming, and reproduction. [3] In human systems, people's life and living environment will be affected by the frequent extreme events, such as floods, storms, droughts, etc. Human health is threatened by heat waves, severe storms, air pollution and diseases linked to climate, especially the vulnerable people.

The current climate change situation is so severe that it has get the worldwide attention and experts have been doing researches on the mitigation and adaptation in different fields.

\subsection{Importance of Buildings}

Buildings are very essential for human beings by providing the foundation for daily activities and habitats for living. They can be not only vulnerable but also obtundent to climate change.

Buildings are vulnerable especially to the extreme events caused by climate change, because there may be an increase in the risk of collapse and significant loss of value as a result from storms, snow or corrosion damage with regional variation.

It is noted in the key findings of IPCC5 that the world's buildings accounted for $32 \%$ of global final energy use and $19 \%$ of all greenhouse gas (GHG) emissions in 2010. [4] And if no action is taken to improve energy efficiency in the building sector, energy demand is expected to rise by $50 \%$ by 2050. [5] The status of building in energy use should be given high attention for it is the largest end-user sector.

There is a potential for energy saving of $50-90 \%$ in existing and new buildings. [4] If proper mitigation technologies and effective policies are implemented perfectly, condition of global climate change will be improved.

For the serious current climate condition and high potential for energy savings in building sector, it can be said that buildings hold important key to effectively addressing climate change by applying mitigation technologies and policies.

\section{Mitigation Technologies and Its Challenges and Opportunities}

As the major contributor to greenhouse gas emissions, "building sector has the largest potential for delivering long-term significant and cost-effective greenhouse emissions reductions". [6] Many mitigation options and technologies are available for both existing and new buildings, and most of them can create co-benefits.

The mitigation technologies and practices can be in five broad mitigation typologies, which can be applied and implemented depending on their own natures.

\subsection{Mitigation Technologies}

\subsubsection{Passive Solar Design}

Passive solar design emphasizes the response of the building to bio-climatic and geographical conditions in its environment. It is related to many building aspects to promote energy efficiency in building sector, such as its form and orientation, insulation of walls, roof and floor, windows-to-wall, glazing type, shading, etc. [7]

Orientation is the most fundamental and easily addressed aspect of solar design. From a southern hemisphere perspective, windows with orientation facing north for more solar accessibility are more energy effective and it is in the contrast orientation from a northern hemisphere perspective. [8]

Building envelope with thermal insulation has a higher chance of improving thermal performance. Passive solar envelope that traps and transmits solar energy into the building will promote energy saving capacity and make full use of solar energy, which could apply in both newly constructed and existing buildings. [9]

Glazing is important in providing daylight and thermal comfort in buildings. Different types of windows should be applied for different applications, for example, windows with low U-value and high total solar energy transmittance for passive solar heating applications and windows with low-e coatings for daylighting applications. [10]

Lots of passive solar design strategies are easy and cost effective to be adopted for newly and existing buildings for highly energy efficiency thus mitigate climate change.

\subsubsection{Active Design}

Active design encompasses technologies, equipment and appliances with highly energy efficient capacity in the building operating stage, such as heating, ventilation and air conditioning (HVAC) systems, lighting systems and water technologies. [11] This strategy will help buildings reduce the electrical energy loads, reduce the cooling or heating load demand to exhaust the heat gains from the equipment. [12]

HVAC system can consume more than $50 \%$ of the total energy consumption of a building in tropical climate. For heating part, condensing boilers are better for mitigating climate change by using natural gas with less pollutions. [13] For cooling part, the use of liquid-based desiccant dehumidification is an effective method to achieve less energy consumption for extracting the moisture of air. [14] Proper kinds of chillers should be chosen depending on the scale and demand of the target building, for example, centrifugal chillers are most efficient for large-capacity operation. For ventilation part, displacement ventilation helps reduce energy demand used by stratifying air. [13]

Energy in lighting could be reduced by applying energy-efficient alternatives, such as energy efficient lamps, ballasts and light fixtures, which can reduce by an estimated $18 \%$ of energy. [11]

Water efficient technologies for buildings often consider about four main water conservation services: bathroom fixture replacement, bathroom fixture optimization for improved efficiency, water re-use and rainwater harvesting systems. [15]

Active design for buildings should be adjusted to local conditions so as to achieve more energy saving. 


\subsubsection{Low Carbon and Carbon Sequestration}

This typology allows buildings to have low embodied carbon and even to neutralize some of the carbon they emit, achieved by selecting low-carbon or carbon-trapped materials and building integrated greenery systems. [11]

Building's embodied carbon can be reduced by utilizing carbon sink and low carbon material and products, such as low-carbon bricks, recycled metals, etc. [16]

Building integrated greenery systems allow buildings to have greenery beyond the ground floor, such as rooftop and facade. Several form and greenery location are developed for reducing cooling load, saving energy and absorbing carbon dioxide, and providing visual amenity. Green roofs, balcony gardens and sky terraces, and green facades/walls [17] are three main forms of greenery systems.

\subsubsection{Onsite Renewable Energy Generation}

This mitigation typology is to support buildings to generate energy from onsite renewable resources, especially solar and wind energy.

Whether solar energy could be used effectively or not depends on the climatic feature. Building integrated photovoltaics (BIPV) is to replace part of vertical external facades or roofs with PV panels or arrays which could be added after the building is built. [18] For achieving long term low-carbon performance, storage for solar energy is needed. PV system may be grid-connected or a stand-alone mode, while stand-alone BIPV systems need energy storage device such as an electrical storage battery. [19]
Wind energy need to be generated by two categories: macro and micro wind turbines. Macro wind turbines need large-scale site, while micro wind turbines can be integrated with buildings for wind energy. And vertical axis wind turbines (VAWTs) become popular for quietness and artistic. [11]

\subsubsection{Occupants' Behavior}

This mitigation typology focuses on the role of occupants in building sector. Occupants' behavior is at the end-use level of building energy consumption. [20] Researches have proved that energy use of similar buildings varies by culture and behavior, [21] such as attire standards and sensitivity to temperature. Also, home area network (HAN) is to connect electrical domestic appliances to smart meters, so that it allows people understand their energy usage patterns by monitoring and measurement and then make a change for energy saving. [11]

This is to say that lifestyle change can produce substantial energy use reduction.

\subsection{Opportunities}

The high potential of building sector to mitigate the climate change can be an important opportunity. It is obvious that Figure 3 shows building sector has the highest estimated potential for GHG mitigation and Figure 4 shows building sector offers the largest low-cost potential in all world regions by 2030. [22]

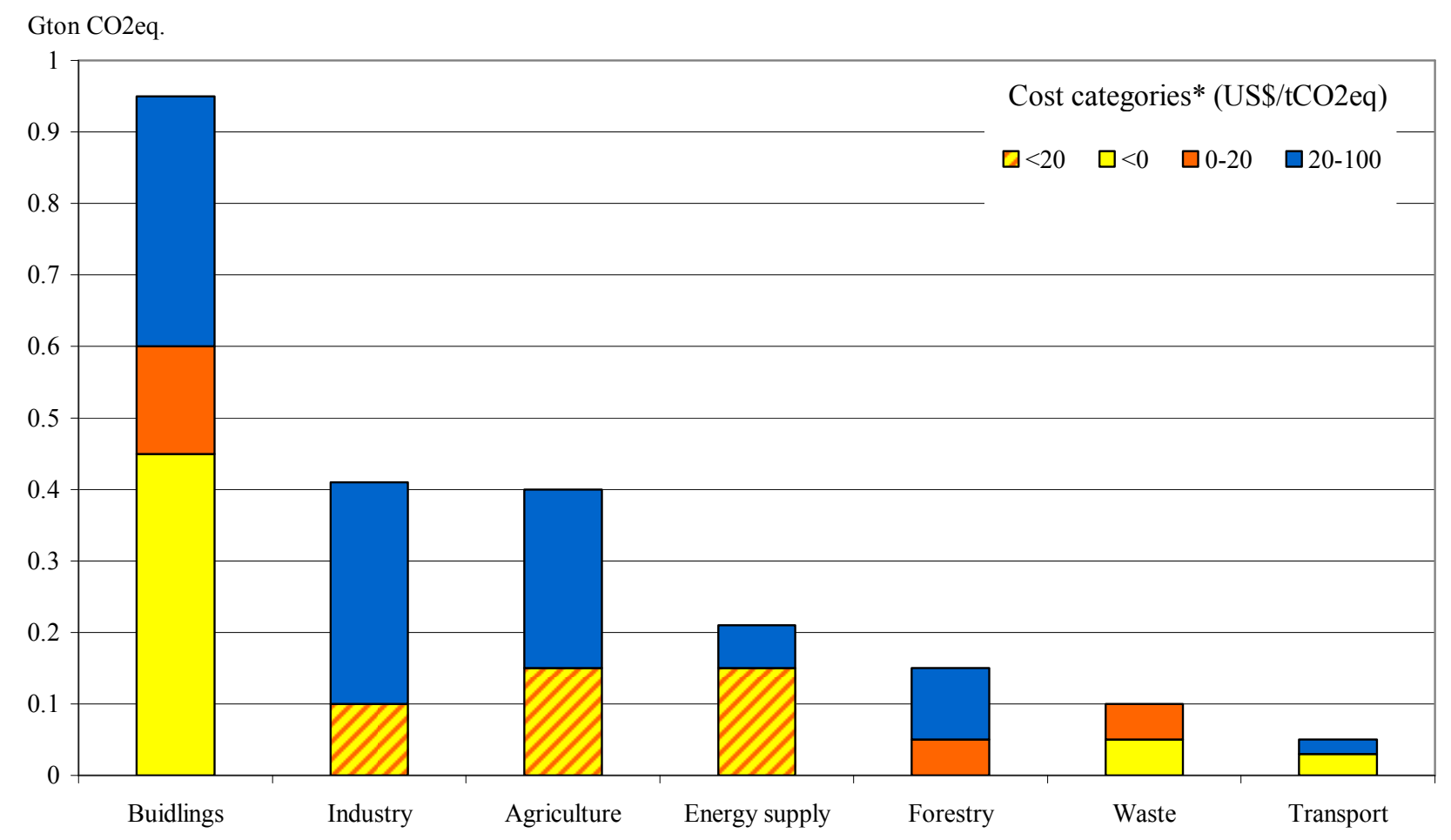

* For the buildings, forestry, waste and transport sectors, the potential is split into three cost categories: at net negative costs, at 0-20 US\$/tCO2, and 20-100 US\$/tCO2. For the industrial, forestry, and energy suppy sectors, the potential is split into two categories: at costs below $20 \mathrm{US} \$ / \mathrm{tCO} 2$ and at $20-100 \mathrm{US} \$ / \mathrm{tCO} 2$.

Figure 3. Estimated potential for GHG mitigation at a sectoral level in 2030 in different cost categories, transition economies [22]. 


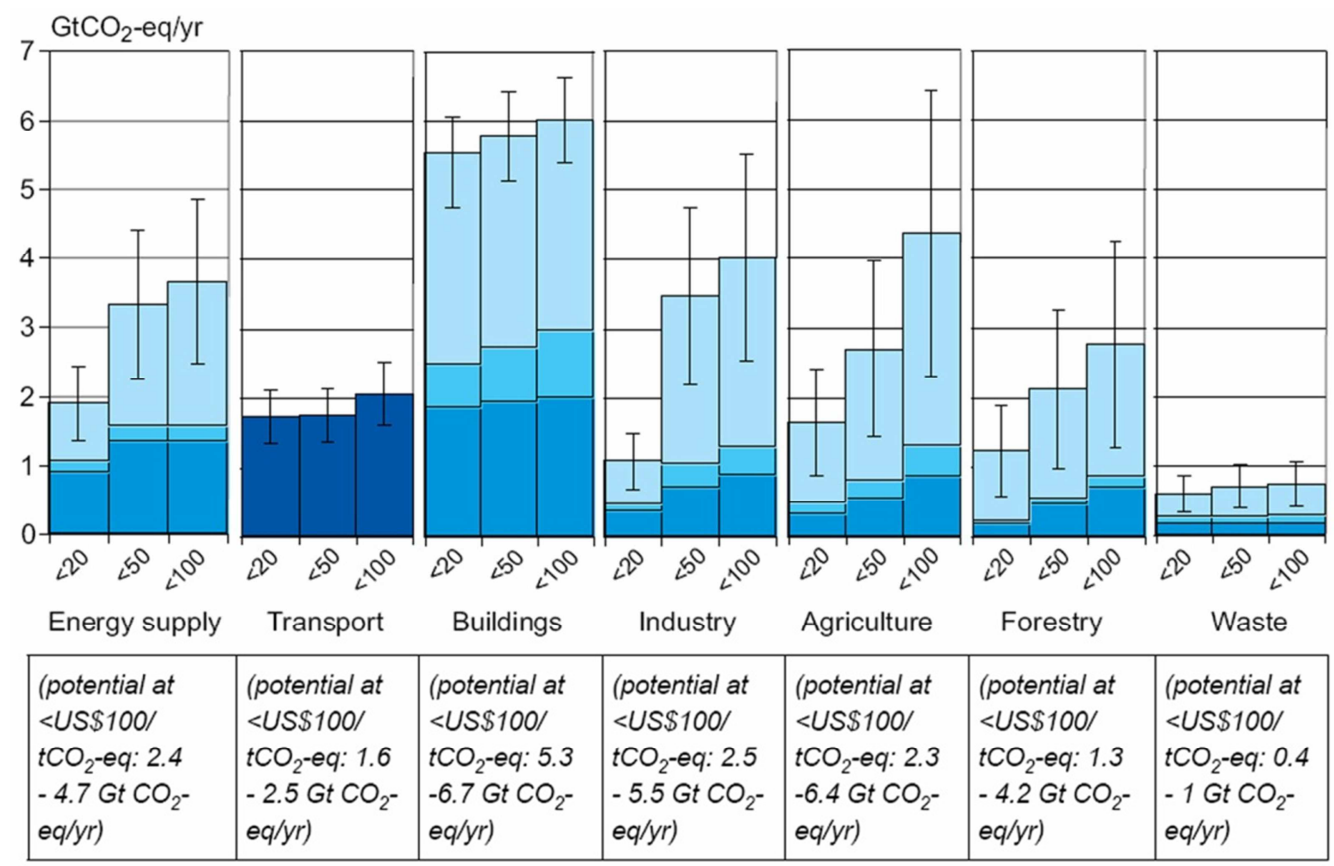

Figure 4. Estimated sectoral economic potential for global mitigation for different regions as a function of carbon price in 2030 from bottom-up studies [22].

Different aspects of mitigation technologies mentioned above offer an opportunity for not only new buildings but also existing buildings to achieve more energy saving. The concept and technologies in zero carbon building offer new buildings an opportunity to achieve the largest savings in the long-term prospect. Additionally, with the opportunity provided by the development of new technologies and new business models, prices for low emission technologies are falling, leading to a rapid growth and acceptance in renewable energy.

The frequent extreme events caused by climate change have put much pressure on new buildings, because some old buildings have survived from extreme events while new buildings were destroyed under many conditions, such as the severe storm in western Norway in 1992. This phenomenon creates opportunities for adopting new efficient technology and knowledge in building sector.

Some economic instruments, such as carbon taxes, and emissions trading scheme, offer developed countries an opportunity to invest in emission reduction projects in other countries, mainly developing countries. These instruments are win-win measures for both developed and developing countries by encouraging the implement of international project.

Besides what be mentioned above, the co-benefits of mitigation in building sector should not be ignored although they are often not quantified, monetized, or identified. Some of them may become important opportunities to promote the mitigation to be applied in building sector, such as the improvement in indoor air quality. [22]

\subsection{Challenges}

Climate change is an international problem. Although the regional work is essential, the international collaboration and coordination is needed to be accelerated to achieve better mitigation. [23] While the challenge is that the collaboration is not easy to form due to the respective benefits of countries or regions.

For financial and technical challenges, split economic interests of different parties in building sector and the lack of knowledge of technologies are the major challenges. The deficiency of accessibility to adequate information and optimal technologies is a challenge to achieve a better performance in energy use reduction. Additionally, energy costs during operating time are often neglected when compared with the current costs in building construction and technologies. [24] The long-term character of energy use should be emphasized in cost and benefit analysis.

Social challenges mainly include the lack of awareness of municipalities and private sectors and the weak policies encouraging mitigation in climate change. Awareness of municipalities and private sectors should be given full consideration for its important role in supporting and executing the mitigation measures and polices. A great challenge for countries is to spread out the awareness. Policies for mitigating climate change should be implemented at an unprecedented scale for new and existing buildings. Policy making for consideration about different stakeholders' benefits and environmental protection is a challenge. And the pace of policy uptake is especially an important challenge in developing countries. [25]

\section{Sectoral Policies}

As many challenges and barriers prevent the implementation for energy saving measures, sectoral policies are necessary to be set because market forces alone will not achieve transformation towards low carbon buildings. 
Common policies for building sector can be summarized in six categories:

\subsection{Regulatory Measures}

Regulatory measures are widely used and are often environmentally effective and cost effective [26], for example, building codes and appliance standards, which often sets standards of minimum requirements of energy performance for buildings. [27]

\subsection{Information Instruments}

Information instruments, including equipment energy labels, building labels and certificates and mandatory energy audits, [21] can be effectively represent their design standards to provide information for users and buyers.

\subsection{Direct Market Intervention}

Direct market intervention instruments include public procurement, which is to set high requirements for buildings or products that public sector purchases or rents. [21] And it can have a great impact on market transformation.

\subsection{Economic Instruments}

Economic instruments are effective to enlarging market for efficient buildings and products, including both tradable permits, taxes and more subsidized loans, which are efficient to overcome the major barriers in cost aspect. [28]

\subsection{Voluntary Agreements}

Voluntary agreements programmes are mainly in industry at national level, but also for equipment and cars, which are in sub-national level. [29] And the voluntary agreements are often implemented with accompanying policy measures to enhance effectiveness.

\subsection{Advice and Leadership Programmes}

Advice and leadership programmes include polices such as information campaigns, advice services, and public leadership programmes, [21] which focus on establish public awareness and knowledge.

Building sectoral polices are adopted by lots of countries to mitigate the climate change in the form of integrating the different instruments together so as to create the largest benefits.

\section{Roles of Different Stakeholders}

The climate change mitigation in building sector need coordination of formal governmental agencies, NGOs, private sectors, and other stakeholders to increase efficiency with agreement and support for climate mitigation measures.

\subsection{Governmental Agencies}

Governmental agencies play an important role in climate mitigation in building sector especially for establishing and enforcing different regulations and imposing taxes to encourage energy efficiency. Additionally, it will be great help in improving knowledge and increasing the accessibility to energy efficient technology or energy, because too little information would be generated without government intervention. [30]

\subsection{Non-government Organizations}

The NGO sector is acknowledged as playing an important advocacy role. Two categories of advocacy are cooperative strategies (such as research and education to better influence policy making) and adversarial strategies (such as mobilization public pressure). [31] NGO sector plays a role in connecting knowledge with responsibility [32] by engaging in policy making process.

\subsection{Private Sector}

Private sector plays a role as the executor for applying proper mitigation measures, encouraging occupier with efficient lifestyles and renovating building to maximum the emission reduction. [33] Fossil fuel companies, as a specific private sector, can promote climate skepticism by providing financial resources to policy makers. [32] Although most of private sectors are restricted by policies, they are important with great power to decide whether and what extent to apply mitigation measures.

\subsection{Research and Educational Institutions}

Research and educational institutions play a role as the instructor by not only finding truth and data which have guiding significance to other stakeholders, but also educating people to reduce emissions and foster long term responsible lifestyles.

No one group of stakeholders can achieve great accomplishments in climate change mitigation in building sector alone. Recognizing their different roles and integrating them together properly can implement the greenhouse emission reduction and mitigate the climate change situation.

\section{Case Study - Norway}

\subsection{Introduction}

Norway, one of the richest countries in the world, has taken the responsibility for contributing reductions in greenhouse gas emissions and mitigation in climate change.

Building sector is a cornerstone of the Norway's economy, which creates lots of employment demand and physical capital. Energy use in building becomes an issue of higher political priority [34] in achieving reduction in energy use.

The climate of Norway is extremely varied graphically and seasonally. And it likely to experience frequent extreme events, such as coastal storms, flooding, avalanches and landslides because of the long coastline and steep topography, [35] which has a great impact on building sector for increasing risks. 


\subsection{Opportunities and Challenges}

\subsubsection{Opportunities}

Mitigation measures taken in building sector has large potential for mitigating climate change in Norway because the construction and operation of buildings account for about $40 \%$ of total energy use in this country. [36] Additionally, this reduction of greenhouse gas emissions will contribute to achieve Norway's Intended Nationally Determined Contribution committed to the UNFCCC (a target of an at least $40 \%$ reduction of greenhouse gas emissions by 2030 compared to 1990 levels [37]). This pressure in achieving the goal will become one of the opportunities.

Furthermore, the new and more climate-friendly technologies and business models provide opportunities for Norway to apply based on the specific climatic characteristics so as to reduce energy use and attain government's overall goal for building to be well designed, safe, energy efficient and healthy. [35]

Taxes, agreements and emissions trading scheme offers Norway, a rich and developed country, an opportunity to fund emission reduction measures and technologies in other countries, mainly developing countries.

\subsubsection{Challenges}

Norway, as a polar nation, has a special responsibility and high vulnerabilities for the climate change.

One of obvious challenges for Norway to mitigate climate change in building sector is the vulnerabilities of buildings. The changing climate has the potential regionally to increase premature deterioration and weathering impacts on built environment, [38] especially in Norway with frequent extreme events. For example, a severe storm in western Norway in 1992 has caused great damages in buildings.

Permafrost in the arctic climate will be a challenge in mitigation in building sector by resulting in destabilization of buildings and other infrastructure, requiring extensive rebuilding, maintenance and investment, which increases the construction and maintenance costs. [39]

The alternative energy supply for the increasing demand of Norway is becoming its own unique urgent challenge, because the supply of clean hydropower cannot meet its increasing demand.

With the international and regional specific opportunities and challenges in applying climate change mitigation in building sector in Norway, different efficient measures should be taken on this large, complex and fragmented building sector.

\subsection{Mitigation Measures}

\subsubsection{Alternatives in Energy Supply}

Norway has a large supply of clean hydropower which is depended on precipitation rates and it is the base of electricity production [40] while it cannot meet the increasing demand. The potential to develop sustainable alternatives, such as solar and wind power, is in practice too small to influence the power balance. Construction of gas-fired power plants with $\mathrm{CO} 2$ sequestration technology is proposed and implemented in the only three gas-fired power plants. [39]

\subsubsection{Reduction in Energy Demand}

The potential of reduction in energy demand is large because construction and operation of building account for about $40 \%$ of all energy use in Norway. [36] Long-lived energy qualities are emphasized in Technical Regulations under the Norwegian Planning and Building Act. It especially encourages to improve thermal insulation and air-tightness of building envelopes in both existing and new buildings, which need consideration combing knowledge on materials, structures and relevant climate and geographic data [39] in the harsh climates.

\subsubsection{Special Programme for Public Awareness}

Education, training and public awareness have been important elements of Norwegian climate policy since the 1990s. [40]

Public awareness campaign on climate change is launched in 2007 to spread information on scientific research. In order to change the current practice and increasing the energy awareness especially in the construction industry part, a comprehensive information and training programme is established for all practitioners to increase the energy competence by complying with the new requirement level. [39] There is no doubt that a spread public awareness on climate change can contribute to accelerate the implement of the mitigation measures for climate change.

\subsubsection{Regulations in Building Sector}

Norway's policy and regulations are one key element of domestic climate policy and two major regulations in building sector are stated below:

The Planning and Building Act (PBA) and Technical Regulations is to label requirements and standards for electrical equipment, various grant schemes and taxes, which can effectively increase the quality of buildings and reduce the amount of building defects. [39]

SINNTEF Building and Infrastructure commissioned by the Norwegian Building Authority emphasized the risk and vulnerability assessment for a number of climate parameters in building construction sector. [35] Different measures and technical regulations for reducing the vulnerability of building are stated by respecting the local climate performance. For example, Figure 5 is one of the national maps of climate zones which is implemented in guidelines on rendered facades and ventilated claddings. [39] 


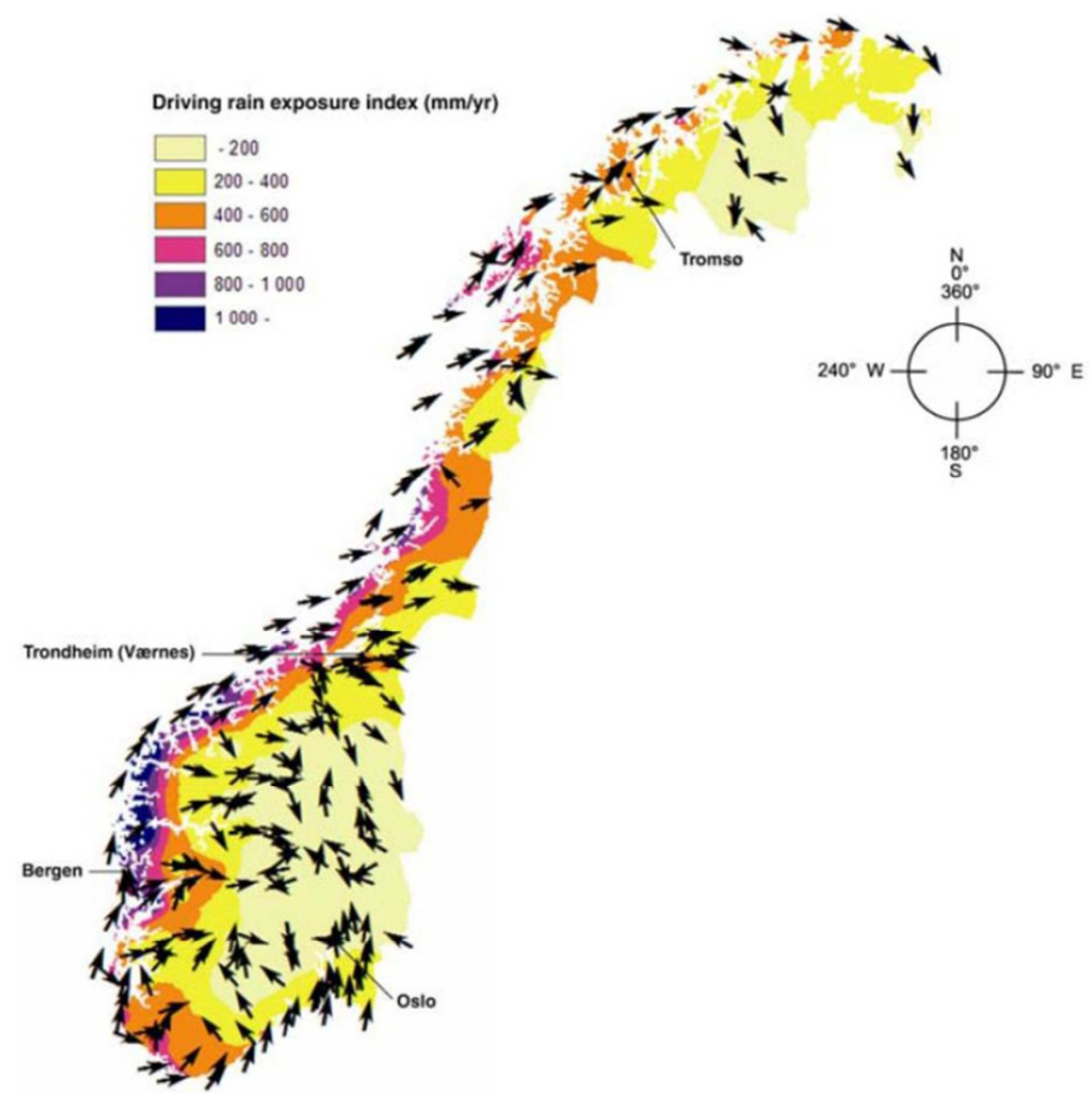

Figure 5. Driving rain map for Norway for the normal period 1961-90 [41].

\subsection{Evaluation}

Besides the mitigation measures mentioned above, different stakeholders in Norway play important roles in mitigation. Research Council of Norway (RCN) plays a central role in research, whose research is the cornerstone of policy making and knowledge spreading. Ministry of Government is responsible for regulation enforcement and municipalities and private sectors are the executors and supervisors who contribute to application of long-term mitigation measures.

So far, Norway has taken the responsibility to make a great effort to global climate change mitigation. And the focal point in this arctic country with specific climate features in building sector is to respect the climate performance. Norway is on the way to achieving the goal in reduction in energy use and greenhouse emissions.

\section{Conclusion}

The global climate change has put pressure on every country to develop and apply climate change mitigation technologies especially in building sector for occupying large proportion in energy use. Integration of sectoral policies and mitigation measures can achieve great efficient energy use and the construction of low-carbon buildings with the effort of different stakeholders.

\section{References}

[1] GlobalChange.gov. (2014), What's Happening \& Why. [online] Available at:

http://www.globalchange.gov/climate-change/whats-happenin g-why [Accessed 29 Mar. 2017].

[2] IPCC. (2014). Climate Change 2014: Synthesis Report. Contribution of Working Group I , II and III to the Fifth Assessment Report of the Intergovernmental Panel on Climate Change. IPCC, Geneva, Switzerland, 155pp.

[3] Epa.gov. (2014). Climate Impacts on Ecosystems. [online] Available at:

https://www.epa.gov/climate-impacts/climate-impacts-ecosyst ems [Accessed 29 Mar. 2017].

[4] Chalmers, P. (2014). Climate Change: Implications for Buildings. ECF, BPIE, GBPN, WBCSD, CJBS \& CISL, $18 \mathrm{PP}$.

[5] IEA. (2013). Transitions to Sustainable Buildings: Strategies and Opportunities to 2050. IEA, Paris, France, 10PP.

[6] UNEP. (2009). Opportunities for Actions with High Mitigation Potential. [online] Available at: http://unfccc.int/resource/docs/2014/smsn/igo/153.pdf [Accessed 2 Apr. 2017].

[7] Stevanvoić, S. (2013). Optimization of Passive Solar Design Strategies: A Review. Renewable and Sustainable Energy Reviews, 25, 177-196. 
[8] Morrissey, J., Moore, T., \& Horne, R. E. (2011). Affordable Passive Solar Design in a Temperate Climate: An experiment in residential building orientation. Renewable Energy, 36(2), 568-577.

[9] Sadineni, S. B., Madala, S., \& Boehm, R. F. (2011). Passive Building Energy Savings: A Review of Building Envelope Components. Renewable and Sustainable Energy Reviews, 15(8), 3617-3631.

[10] Singh, M. C., \& Garg, S. N. (2009). Energy Rating of Different Glazings for Indian Climates. Energy, 34(11), 1986-1992.

[11] Cam, W. C. (2012). Technologies for Climate Change Mitigation: Building Sector. UNEP. New Delhi: Magnum Custom Publishing, 197PP.

[12] Jones, P., Hou, S. S., \& Li, X. (2015). Towards Zero Carbon Design in Offices: Integrating Smart Facades, Ventilation, and Surface Heating and Cooling. Renewable Energy, 73, 69-76.

[13] Graham C. I. (2009). High-Performance HVAC. In Whole Building Design Guide. Washington D.C.: National Institute of Building Sciences. [Online] Available at: www.wbdg.org/resources/hvac.php [Accessed 4 Apr. 2017].

[14] Chua, K. J., Chou, S. K., Yang, W. M., \& Yan, J. (2013). Achieving better energy-efficient air conditioning-a review of technologies and strategies. Applied Energy, 104, 87-104.

[15] Turner, S. (2015). WET ${ }^{\mathrm{TM}}$ - Water Efficient Technologies. Healthy Buildings. Available at: http://healthybuildings.com/wet-water-efficient-technologies/ [Accessed 4 Apr. 2017].

[16] Cam, W. C. (2012). Carbon Sink and Low-carbon Building Materials. ClimateTechWiki. [Online] Available at: http://www.climatetechwiki.org/technology/carbon-sink-and-l ow-carbon-building-materials [Accessed 4 Apr. 2017].

[17] Cam, W. C. (2012). Greening the Built Environment. ClimateTechWiki. [Online] Available at: http://www.climatetechwiki.org/technology/greening-built-env ironment [Accessed 4 Apr. 2017].

[18] Lenardic, D. (2015). BIPV - Building Integrated Photovoltaics. Pvresources.com. [online] Available at: http://www.pvresources.com/en/bipv/bipv.php [Accessed 4 Apr. 2017].

[19] Dresser, C. \& McKee International Inc. (2002). Study on the potential applications of renewable energy in Hong Kong. Hong Kong: Electrical \& Mechanical Services Department.

[20] Yu, Z., Fung, B. C., Haghighat, F., Yoshino, H., \& Morofsky, E. (2011). A Systematic Procedure to Study the Influence of Occupant Behavior on Building Energy Consumption. Energy and Buildings, 43(6), 1409-1417.

[21] Lucon O., D. Ürge-Vorsatz, A. Zain Ahmed, H. Akbari, P. Bertoldi, L. F. Cabeza, N. Eyre, A. Gadgil, L. D. D. Harvey, Y. Jiang, E. Liphoto, S. Mirasgedis, S. Murakami, J. Parikh, C. Pyke, and M. V. Vilariño. (2014). Buildings. In: Climate Change 2014: Mitigation of Climate Change. Contribution of Working Group III to the Fifth Assessment Report of the Intergovernmental Panel on Climate Change. Cambridge and New York: Cambridge University Press, 68PP.

[22] D. Ürge-Vorsatz. (2007). Climate Change Mitigation in the Building Sector. [online] Available at: https://www.ipcc.ch/pdf/presentations/poznan-COP-14/diane- urge-vorsatz.pdf [Accessed 4 Apr. 2017].

[23] Lambert, G. (2015). Leading Global Collaboration in Climate Change Standards. [online] Available at: https://www.iso.org/news/2015/12/Ref2031.html [Accessed 6 Apr. 2017].

[24] UNEP \& SBCI. (2009). Submission of the United Nations Environment Programme (UNEP) Sustainable Building Initiative (SBCI) to the Ad Hoc Working Group on Long-Term Cooperative Action under the Convention (AWG-LCA). [online] Available http://unfccc.int/resource/docs/2009/smsn/igo/044.pdf [Accessed 6 Apr. 2017].

[25] Williams, C. Hasanbeigi, A. Wu, G \& Price, L. (2012). International Experience with Quantifying the Co-Benefits of Energy Efficiency and Greenhouse Gas Mitigation Programs and Policies. [online] Available at: https://china.lbl.gov/sites/all/files/co-benefit-executive-summa ry-english.pdf [Accessed 6 Apr. 2017].

[26] IPCC. (2014). Climate Change 2014: Synthesis Report. Contribution of Working Groups I, II and III to the Fifth Assessment Report of the Intergovernmental Panel on Climate Change. IPCC, Geneva, Switzerland, 151 pp.

[27] Boza-Kiss, B., Moles-Grueso, S., \& Urge-Vorsatz, D. (2013). Evaluating policy instruments to foster energy efficiency for the sustainable transformation of buildings. Current Opinion in Environmental Sustainability, 5(2), 163-176.

[28] McGilligan, C., Sunikka-Blank, M., \& Natarajan, S. (2010). Subsidy as an agent to enhance the effectiveness of the energy performance certificate. Energy Policy, 38(3), $1272-1287$

[29] Bertoldi, P. (2011). Assessment and Experience of White Certificate Schemes in the European Union. European Commission, Directorate General JRC.

[30] OUPblog. (2014). What is the Role of Governments in Climate Change Adaptation. [online] Available at: https://blog.oup.com/2014/07/government-adaptation-climatechange/ [Accessed at 9 Apr. 2017]

[31] Szarka, J. (2013). From climate advocacy to public engagement an exploration of the roles of environmental non-governmental organisations. Climate, 1(1), 12-27.

[32] Somanathan E., T. Sterner, T. Sugiyama, D. Chimanikire, N. K. Dubash, J. Essandoh-Yeddu, S. Fifita, L. Goulder, A. Jaffe, X. Labandeira, S. Managi, C. Mitchell, J. P. Montero, F. Teng, and T. Zylicz. (2014). National and Sub-national Policies and Institutions. In: Climate Change 2014: Mitigation of Climate Change. Contribution of Working Group III to the Fifth Assessment Report of the Intergovernmental Panel on Climate Change. Cambridge and New York: Cambridge University Press, 66PP.

[33] Sbci, U. N. E. P. (2009). Buildings and climate change: Summary for decision-makers. United Nations Environmental Programme, Sustainable Buildings and Climate Initiative, Paris, 62PP.

[34] The Research Councl of Norway Clean Energy for the Future (RENERGI). Clean Energy for the Future - from Vision to True Alternative. (2013). Oslo: The Research Councl of Norway, 65PP.

[35] Norwegian Ministry of Climate and Environment. (2012). Climate Change Adaptation in Norway. Oslo: Norwegian Ministry of Climate and Environment, 107PP. 
[36] Haase, M., Buvik, K., Dokka, T. H. \& Andresen, I. (2010). Guidelines for Energy Efficiency Concepts in Office Buildings in Norway. Oslo: SINTEF Building and Infrastructure. 64PP.

[37] Norway. (2015). Norway's Intended Nationally Determined Contribution. [online] Available at:

http://www4.unfccc.int/submissions/INDC/Published\%20Doc uments/Norway/1/Norway\%20INDC\%2026MAR2015.pdf [Accessed 10 Apr. 2017]

[38] Climatechangepost.com. (2014). Transport, Infrastructure and Building in Norway. [online] Available at: http://www.climatechangepost.com/norway/transport-infrastru cture-and-building/ [Accessed 10 Apr. 2017].
[39] Lisø, K. B., Myhre, L., Kvande, T., Thue, J. V. \& Nordvik, V. (2007). A Norwegian perspective on buildings and climate change. Building Research \& Information, 35(4), 437-449.

[40] Norwegian Ministry of Climate and Environment. (2014). Norway's Sixth National Communication - Under the Framework Convention on Climate Change. Oslo: Norwegian Ministry of Climate and Environment. 300PP.

[41] Lisø, K. R. (2006). Building Envelope Performance Assessments in Harsh Climates: Methods for Geographically Dependent Design. Doctoral Theses 2006: 185, Faculty of Engineering Science and Technology, Department of Civil and Transport Engineering, Norwegian University of Science AND Technology. 